\title{
Author Correction: Call for Proposals Articles for a Special Issue of Public Organization Review (POR) on Global Responses to the COVID-19 Pandemic
}

\author{
Ali Farazmand ${ }^{1} \cdot$ Frances Edwards $^{2} \cdot$ Steven Ott $^{3}$ \\ Published online: 26 February 2021 \\ (C) Springer Science+Business Media, LLC, part of Springer Nature 2021
}

\section{Author Correction: Public Organization Review https://doi.org/10.1007/s11115-020-00495-0}

The original version of this article unfortunately contained a mistake. The first paragraph under "Timetable to Publication" section should read as:

Interested scholars are invited to submit proposals of approximately 800 to 1000 words POR by January 30, 2021. Manuscripts will go through rigorous double blind-reviews. Proposing authors will be notified by February 15-20, 2021.

The original article has been corrected.

Publisher's Note Springer Nature remains neutral with regard to jurisdictional claims in published maps and institutional affiliations.

The online version of the original article can be found at https://doi.org/10.1007/s11115-020-00495-0

Ali Farazmand

afarazma@fau.edu

Frances Edwards

kc6thm@yahoo.com

Steven Ott

jsott@cppa.utah.edu

1 Florida Atlantic University, Boca Raton, FL, USA

2 San Jose State University, San Jose, CA, USA

3 University of Utah, Salt Lake City, UT, USA 